\title{
Occurrence of the bigeye thresher shark, Alopias superciliosus (Lowe, 1841) (Elasmobranchii, Alopiidae) in the southwestern Gulf of Mexico
}

\author{
Luis Fernando Del Moral-Flores ${ }^{1}(\mathbb{D})$, Jorge Pérez-Díaz ${ }^{1}$ \\ Tao Hernández-Arellano ${ }^{1,2} \mathbb{C}$ \& Eduardo López-Segovia ${ }^{1,3}$ \\ ${ }^{1}$ Laboratorio de Zoología, Facultad de Estudios Superiores Iztacala \\ Universidad Nacional Autónoma de México, Tlalnepantla, Estado de México, México \\ ${ }^{2}$ KAI Ocean Labs, 5799 Cunard Street, Nova Scotia B3K 1C9, Canada \\ ${ }^{3}$ Posgrado en Ciencias del Mar y Limnología, Universidad Nacional Autónoma de México \\ Coyoacán, Ciudad de México, México \\ Corresponding author: Luis Fernando Del Moral-Flores (delmoralfer@comunidad.unam.mx)
}

\begin{abstract}
The bigeye thresher shark Alopias supeciliosus is a large epipelagic and mesopelagic species, and it has a wide distribution in the Atlantic. However, its record in the Gulf of Mexico is sporadic. A single adult female of A. superciliosus, measuring $360 \mathrm{~cm}$ total length and about weight $165 \mathrm{~kg}$, was caught by artisanal fishers in Salinas Roca Partida, Veracruz, Mexico, on July 14, 2020. This study reports the first occurrence of this species in the southwestern of the Gulf of Mexico, which extends its geographical distribution in Mexico.
\end{abstract}

Keywords: Alopias superciliosus; Lamniformes; Chondrichthyes; new record; pelagic sharks; western Atlantic

The knowledge of the biology and ecology of pelagic sharks is relatively minor compared to coastal species due to the difficulty of studying widely distributed and highly vagile species and with sporadic records within catches (Pikitch et al. 2008). One of these groups is called fox sharks or sea foxes; they belong to the Alopiidae family. They are characterized by having long caudal fins, notable extension of the dorsal lobe of the caudal fin. Three species are recognized as common thresher (Alopias vulpinus), pelagic thresher (A. pelagicus), and bigeye thresher (A. superciliosus) and are often caught in longline fisheries and incidentally in fishing nets (Compagno 2002, Castro 2011).

The bigeye thresher shark, Alopias superciliosus (Lowe, 1840), is a large shark with a maximum total length of approximately $460 \mathrm{~cm}$, distributed worldwide in tropical and temperate seas (Young et al. 2016). It is an epipelagic, neritic and epibenthic species found in coastal waters and high seas; its bathymetric range reaches $900 \mathrm{~m}$ depth with daily vertical migration
(Compagno 2002, Coelho et al. 2015). They are aplacental viviparous species with intrauterine oophagy; low fecundity, on average two embryos per litter, although four embryos have been reported, the gestation period is 12 months (Moreno \& Morón 1992, Chen et al. 1997, Young et al. 2016) and in the adult state they can reach 17 years in male and up to 22 years in females (Fernandez-Carvalho et al. 2011). It is a specialist predator, feeding on various teleost fish, cephalopods, and crustaceans (Polo-Silva et al. 2007).

It is considered a species with Pan-Atlantic distribution, the range of known distribution in the western Atlantic from New York to northern Argentina (Fernandez-Carvalho et al. 2015), including Florida, Bahamas, Cuba, Caribbean, and Gulf of Mexico (Compagno 2002, Castro 2011). However, the presence inside the Gulf of Mexico is barely documented. The first record of A. superciliosus in the Gulf of Mexico was reported by Branstetter \& McEachran (1983), based on a female captured in north Texas at a closet

Corresponding editor: Leonardo Abitia 


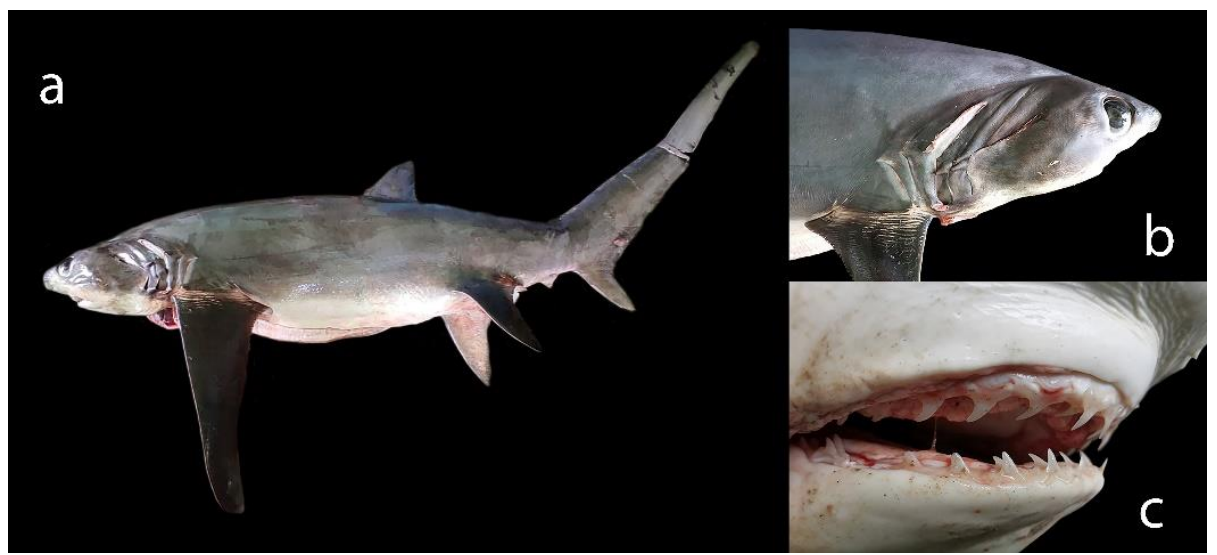

Figure 1. Female bigeye thresher shark Alopias superciliosus, $360 \mathrm{~cm}$ total length, caught in the southwestern Gulf of Mexico. a) Lateral view, b) lateral view of the head, c) oral view.

depth of $400 \mathrm{~m}$ and an adult male in south Texas, both by commercial longline. Later, its presence was recorded in the northern parts of the Gulf of Mexico, and because of this, it is considered one of the rarest oceanic shark species found in this sea (Russell 1993, Baum \& Myers 2004). On the Mexican coast of the Gulf of Mexico, the bigeye thresher shark has been mentioned. However, there are no signs of its presence (Castillo-Géniz et al. 1998) and sight in Los Tuxtlas (Schaldach et al. 1997). Nevertheless, this has no valid evidence even when there is a record near the continental shelf of Yucatan, Mexico (Bonfil 1997, Del Moral-Flores et al. 2015). This work aims to report its presence and morphometric data in the southwest Gulf of Mexico and the Mexican coast.

An adult of $A$. superciliosus was captured incidentally by a fisher, on July 15,2020 , by a long line (2000 $\mathrm{m}$ in length and 200 hooks of number 6) at a depth of $30 \mathrm{~m}$, approximately $5 \mathrm{~km}$ offshore of the locality of the Salina Roca Partida, located at $18^{\circ} 42^{\prime} 17.3^{\prime \prime} \mathrm{N}, 95^{\circ} 14^{\prime} 19.9^{\prime \prime} \mathrm{W}$. The specimen, a female, measured $370 \mathrm{~cm}$ in total length (TL) and weighed 150 $\mathrm{kg}$ without organs (Fig. 1). The jaw, pectoral fins and caudal dorsal lobe are deposited in the Colección Ictiológica de la FES-Iztacala (CIFI-1414), Mexico. The taxonomic determination was made using specialized keys from the area (Castro 2011) and the morphometry of the organism (Table 1). Because the specimen had no viscera, it was impossible to determine exactly the degree of sexual maturity. According to the studies, the size of the first maturity reaches between 332 to $350 \mathrm{~cm}$ TL and 202 to $208.6 \mathrm{~cm}$ fork length (Moreno \& Morón 1992, Chen et al. 1997, Fernandez Carvalho et al. 2015), so it could be considered a mature female and over 12 years old. Later, it was processed by the fishing cooperative and sent to the "La Nueva Viga" market for its commercialization. Several sharks and rays have been registered in this market from both coasts of Mexico (Ballesteros-Hernández et al. 2019).

The characteristics of this specimen were consistent with the description of $A$. superciliosus reported in the literature (Gruber \& Compagno 1981, Compagno 2002). The following characters recognized the species: lateral grooves above the branchial region; bulbous snout, large eye, extend to the dorsal part of the head; the first dorsal fin is positioned more posterior on the back, with the midpoint of its base much closer to the bases pelvic fin; the dorsal extension of the caudal fin is similar to the precaudal length; pectoral fins are broadly pointed. The coloration of the dorsal-lateral region is brownish gray and in the ventral area whitish with grayish tones.

The lack of specific studies and the consideration of the historical records of pelagic sharks, such as the bigeye thresher shark, have generated a dilemma about their presence, native or exotic, in different seas (Corsini-Foka \& Sioulas 2009). This study provides the first record of A. superciliosus and information about his distribution on the Mexican coast of the Gulf of Mexico. The new records of other oceanic species of sharks may be correlated with the increase in studies and observations in the area. However, it may also be considered an expansion of their distribution due to the emptiness of ecological niches by others species that have suffered a population decline (Burges et al. 2005). Likewise, we must point special attention must be considered when reporting their common names, as they can confuse and underestimate specific richness. In the Gulf of Mexico, it has been recorded that $A$. superciliosus generally resides in shallower depths at night and greater depths during the day (Weng \& Block 
Table 1. Morphometric data of the adult bigeye thresher shark Alopias superciliosus caught in the southwestern Gulf of Mexico. TL: total length.

\begin{tabular}{lcc}
\hline Measurements & Length $(\mathrm{cm})$ & Proportion of TL (\%) \\
\hline Total length & 356 & \\
Fork length & 271 & 76.1 \\
Snout to 1rs branchial & 45 & 12.6 \\
Snout to 2 branchial & 48 & 13.5 \\
Snout to 3 branchial & 51 & 14.3 \\
Snout to 4 branchial & 55 & 15.4 \\
Snout to 5 branchial & 57 & 16.0 \\
Eye length & 7 & 2.0 \\
Predorsal length & 69 & 19.4 \\
Prepectoral length & 52 & 14.6 \\
Pectoral-fin anterior margin & 75 & 21.1 \\
Pectoral-fin posterior margin & 73.5 & 20.6 \\
Pectoral-fin inner margin & 11 & 3.1 \\
Pelvic-fin anterior margin & 35.7 & 10.0 \\
Pelvic-fin posterior margin & 38.5 & 10.8 \\
Pelvic-fin inner margin & 7.5 & 2.1 \\
Anal-fin anterior margin & 6 & 1.7 \\
Anal-fin posterior margin & 8 & 2.2 \\
Anal-fin inner margin & 7 & 2.0 \\
First dorsal-fin anterior margin & 32 & 9.0 \\
First dorsal-fin posterior margin & 28.5 & 8.0 \\
First dorsal-fin inner margin & 7.5 & 2.1 \\
Second dorsal-fin anterior margin & 4 & 1.1 \\
Second dorsal-fin posterior margin & 6.5 & 1.8 \\
Second dorsal-fin inner margin & 7 & 2.0 \\
Upper lobe of the caudal-fin dorsal margin & 106.5 & 29.9 \\
Lower lobe of the caudal-fin ventral margin & 28 & 7.9 \\
\hline
\end{tabular}

2004). These daily movements and the migratory ones may be related to food (Polo-Silva et al. 2007). Although slight evidence of declining populations of fox sharks in the western Atlantic, including the Gulf of Mexico and the Caribbean, their records have been sparse, making it impossible to understand better their populations (Cortes et al. 2007).

The species is listed as vulnerable in the International Union for Conservation of Nature (IUCN) red list (Rigby et al. 2019). Due to the few records in the region, the population status in the Gulf of Mexico is unknown. The record, together with the recent contribution of the elasmobranchs in the southwestern Gulf of Mexico (Del Moral-Flores \& Paleo-Delgado 2018, Del Moral-Flores et al. 2020), show the limited knowledge of their diversity and distribution in the region. Therefore it is necessary to carry out specific research to understand their primary population data regarding proper handling and conservation.

\section{ACKNOWLEDGMENTS}

We thank the Salinas Roca Partida fishermen, especially Gregorio Pio Campo and Martín Echeverría Hernández for providing the specimen of this contribution, also to biology student A.A. JiménezHernández for your help in the fieldwork. This work was supported by UNAM-PAPIIT IA207820. We appreciate the support of SNI-CONACyT.

\section{REFERENCES}

Ballesteros-Hernández, S., Del Moral-Flores, L.F. \& Sánchez-Cárdenas, R. 2019. Los tiburones y rayas comercializados en el mercado de La Nueva Viga, Ciudad de México: lista sistemática y estado de conservación. Ciencia Pesquera, 27: 27-38.

Baum, J.K. \& Myers, R.A. 2004. Shifting baselines and the decline of pelagic sharks in the Gulf of Mexico. Ecology Letters, 7: 135-145. doi: 10.1111/j.14610248.2003.00564.x 
Bonfil, R. 1997. Status of shark resources in the southern Gulf of Mexico and Caribbean: implications for management. Fisheries Research, 29: 101-117. doi: 10.1016/S0165-7836(96)00536-X

Branstetter, S. \& McEachran, J.D. 1983. A first record of the bigeye thresher, Alopias superciliosus, the blue shark, Prionace glauca, and the pelagic stingray, Dasyatis violacea, from the Gulf of Mexico. Northeast Gulf Science, 6: 59-61. doi: 10.18785/negs.0601.07

Burges, G.H., Beerkircher, L.R., Cailliet, G.M., Carlson, J.K., Cortés, E., Goldman, K.J., et al. 2005. Is the collapse of shark population in the Northwest Atlantic Ocean and the Gulf of Mexico real? Fisheries, 30: 1926. doi: 10.1577/1548-8446(2005)30[19:ITCOSP]2.0. $\mathrm{CO} ; 2$

Castillo-Geniz, J.L., Márquez-Farías, J.F., Rodriguez de la Cruz, M.C., Cortés, E. \& Cid del Prado, A. 1998. The Mexican artesanal shark fishery in the Gulf of Mexico: towards a regulated fishery. Marine and Freshwater Research, 49: 611-620. doi: 10.1071/MF97120

Castro, J.I. 2011. The sharks of North America. Oxford University Press, New York.

Chen, C.-T., Liu, K.M. \& Chang, Y.C. 1997. Reproductive biology of the bigeye thresher shark, Alopias superciliosus (Lowe, 1839) (Chondrichthyes: Alopiidae), in the northwestern Pacific. Ichthyological Research, 44: 227-235. doi: 10.1007/BF02678702

Coelho, R., Fernandez-Carvalho, J. \& Santos, M.N. 2015. Habitat use and diel vertical migration of bigeye thresher shark: overlap with pelagic longline fishing gear. Marine Environmental Research, 112: 91-99. doi: 10.1016/j.marenvres.2015.10.009

Compagno, L.J.V. 2002. Sharks of the world. An annotated and illustrated catalogue of shark species known to date. Bullhead, mackerel, and carpet sharks (Heterodontiformes, Lamniformes, and Orectolobiformes). FAO Species Catalogue for Fishery Purposes 2. FAO, Roma.

Corsini-Foka, M. \& Sioulas, A. 2009. On two old specimens of Alopias superciliosus (Chondrichthyes: Alopiidae) from the Aegean waters. Marine Biodiversity Records, 2: e72. doi: 10.1017/S1755267209 00044X

Cortes, E., Craig, A.B. \& Beerkircher, L.R. 2007. Relative abundance of pelagic sharks in the Western North Atlantic Ocean, including the Gulf of Mexico and the Caribbean Sea. Gulf and Caribbean Research, 19: 3752. doi: $10.18785 /$ gcr. 1902.06

Del Moral-Flores, L.F. \& Paleo-Delgado, S. 2018. Confirmación de la presencia del tiburón cadena, Scyliorhinus retifer (Garman, 1881), en el suroeste del Golfo de México. Revista Ciencias Marinas y Costeras, 10: 95-103. doi: 10.15359/revmar.10-2.5
Del Moral-Flores, L.F., Meza-Abundio, I. \& PérezEspaña, H. 2020. First confirmed record of the occurrence of the lesser devil ray, Mobula hypostoma (Elasmobranchii, Mobulidae), in the southwestern Gulf of Mexico. Latin American Journal of Aquatic Research, 84: 696-699. doi: 10.3856/vol48-issue4fulltext-2459

Del Moral-Flores, L.F., Morrone, J.J., Alcocer Durand, J., Espinosa-Pérez, H. \& Pérez-Ponce de León, G. 2015. Lista patrón de los tiburones, rayas y quimeras (Chondrichthyes, Elasmobranchii, Holocephali) de México. Arxius de Miscel-lània Zoològica, 13: 47163. doi: 10.32800/amz. 2015.13.0047

Fernandez-Carvalho, J., Coelho, R., Erzini, K. \& Neves Santos, M. 2011. Age and growth of the bigeye thresher shark, Alopias supercilious, from the pelagic longline fisheries in the tropical northeastern Atlantic Ocean, determined by vertebral band counts. Aquatic Living Resources, 24: 359-368. doi: 10.1051/alr/ 2011046

Fernandez-Carvalho, J., Coelho, R., Mejuto, J., Cortés, E., Domingo, A., Yokawa, K., et al. 2015. Pan-Atlantic distribution patterns and reproductive biology of the bigeye thresher, Alopias superciliosus. Reviews in Fish Biology and Fisheries, 25: 551-568. doi: 10.1007/s11160-015-9389-7

Gruber, S.H. \& Compagno, L.J.V. 1981. Taxonomic status and biology of the bigeye thresher, Alopias superciliosus. Fisheries Bulletin, 79: 617-640.

Moreno, J.A. \& Morón, J. 1992. Reproductive biology of the bigeye thresher shark, Alopias superciliosus (Lowe, 1839). Australian Journal of Marine and Freshwater Research, 43: 77-86. doi: 10.1071/MF 9920077

Pikitch, E.K., Camhi, M.D. \& Babcock, E.A. 2008. Introduction to sharks of the open ocean. In: Camhi, M.D., Pikitch, E.K. \& Babcock, E.A. (Eds.). Sharks of the open ocean: biology, fisheries and conservation. Blackwell Publishing, Oxford, pp. 3-13.

Polo-Silva, C., Baigorrí-Santacruz, A., Galván-Magaña, F., Grijalba-Bendeck, M. \& Sanjuan-Muñoz, A. 2007. Hábitos alimentarios del tiburón zorro Alopias superciliosus (Lowe, 1839), en el Pacífico ecuatoriano. Revista de Biología Marina y Oceanografía, 42: 59-69. doi: 10.4067/S0718-19572007000100007

Rigby, C.L., Barreto, R., Carlson, J., Fernando, D., Fordham, S., Francis, M.P., et al. 2019. Alopias superciliosus. The IUCN Red List of Threatened Species 2019. [https://dx.doi.org/10.2305/IUCN.UK. 2019-3.RLTS.T161696A894216.en]. Reviewed: July 29, 2020.

Russell, S.J. 1993. Shark bycatch in the northern Gulf of Mexico tuna longline fishery, 1988-91, with observations on the nearshore directed shark fishery. In: Branstetter, S. (Ed.). Conservation biology of elasmo- 
branchs. NOAA Technical Report NMFS 115, pp. 1929.

Schaldach, W.L., Huidobro-Campos, L. \& Espinosa Pérez, H. 1997. Peces marinos. In: González-Soriano, E., Dirzo, R. \& Vogt, R.C. (Eds.). Historial natural de Los Tuxtlas. UNAM-CONABIO, Ciudad de México, pp. 463-471.

Received: 28 August 2020; Accepted: 23 March 2021
Weng, K.C. \& Block, B.A. 2004. Diel vertical migration on the bigeye thresher shark (Alopias superciliosus), a species possessing orbital retia mirabilia. Fishery Bulletin, 102: 221-229.

Young, C.N., Carlson, J., Hutchinson, M., Kobayashi, D., McCandless, C., Miller, M.H., et al. 2016. Status review report: common thresher shark (Alopias vulpinus) and bigeye thresher shark (Alopias superciliosus). Final Report to National Marine Fisheries Service, Office of Protected Resources. NOAA, Portland. 